\title{
Effects of organic acid on the physicochemical properties of gelatine extracted from Fringescale sardinella (Sardinella fimbriata) bones
}

\author{
${ }^{1}$ Arshad, N.M., ${ }^{2}$ Abd. Ghaffar, M. and ${ }^{1, *}$ Mohtar, N.F. \\ ${ }^{1}$ Faculty of Fisheries and Food Science, Universiti Malaysia Terengganu, 21030 Kuala Nerus, Terengganu, \\ Malaysia. \\ ${ }^{2}$ Faculty of Science and Marine Environment, Universiti Malaysia Terengganu, 21030 Kuala Nerus, \\ Terengganu.
}

\author{
Article history: \\ Received: 15 January 2021 \\ Received in revised form: 27 \\ February 2021 \\ Accepted: 3 April 2021 \\ Available Online: 18 August \\ 2021
}

Keywords:

Extraction,

Gelatine,

Organic acid,

Physico-chemical,

Sardinella fimbriata

DOI:

https://doi.org/10.26656/fr.2017.5(4).038

\begin{abstract}
Gelatine from marine sources especially from the fish becomes a popular alternative to replace the commercial gelatines from bovine and porcine. Fringescale sardinella (Sardinella fimbriata) is commonly used in the fish processing industry and has a high potential to produce gelatine from its by-products. The extraction of gelatine is one of the most important steps that influence its functional properties. Inorganic acid was commonly used in the extraction, however, nowadays it faces some issues due to health safety and its effect on the environment. The aim of this study was to assess the effects of organic acid (fruit vinegar) as a replacement for inorganic acid (hydrochloric acid) during extraction on the physicochemical properties of S. fimbriata gelatine. The extracted gelatines were characterized in terms of their physico-chemical properties such as the yield percentage, gel strength, melting point, molecular weight, structural composition, and amino acid analyses. Results showed that gelatine extracted with organic acid demonstrated low yield percentage $(2.9 \pm 0.01 \%)$ and poor gel strength $(75.9 \pm 1.06 \mathrm{~g})$ and melting point $\left(22.0 \pm 1.00^{\circ} \mathrm{C}\right)$ values compared to the standard. This gelatine also demonstrated a low amount of proline and hydroxyproline contents, which were $43.77 \pm 8.21 \mathrm{~g} / \mathrm{mg}$ and $34.99 \pm 6.50 \mathrm{~g} / \mathrm{mg}$, respectively. Overall findings have suggested that different types of acid used in the extraction resulted in different physico-chemical properties of the gelatine. Such findings suggested that $S$. fimbriata bone hold the potential to be an alternative source for vast applications in industries. Further studies may focus on different concentrations of acid used in the extraction process. Such findings will help to improve $S$. fimbriata bone gelatine properties for extended uses in various industries.
\end{abstract}

\section{Introduction}

Sardinella fimbriata is one of the most commercial marine species in Malaysia especially for local consumption and economic development. It is commonly found in the coastal area especially in the East Coast regions such as Terengganu, Kelantan and Pahang. It is locally known as Tamban (Ambak et al., 2010). It has high commercial value due to its high demand from the food industry to produce otoshimi, keropok lekor and other fisheries products. The high demand for this marine species has led to high production of by-products such as skin, scales, head and bone, which was estimated at around $22 \%$. Such by-products contain up to $30 \%$ of high-value collagen (Gòmez-Guillèn et al., 2002). However, the discarded by-products are commonly transformed into a low economic product or commonly discarded into the sea (Khiari et al., 2011). As the fishery by-product industries are developing, it has produced more by-products thus affecting the environment in the long run. The utilisation of fish by-products into high value-added products is important for the environment to reduce the organic contaminant charge (Jespersen et al., 2000). Therefore, this study was proposed to utilize waste into wealth. This indirectly may contribute to reducing the impact on the environment and increase sustainable economic development among locals.

Gelatine is one of the high-value by-products that can be derived from fisheries waste such as skin, scales, head and bone. It can be derived from the partial hydrolysis of collagen. It is a protein collected from 
animal by-products that can be obtained through partial hydrolysis of collagen found in connective tissue, bones, and some of the intestines of animals (Mohtar et al., 2010). One unique property of the gelatine is its thermorevesibility which is able to turn solid into a liquid when heated and turn back to the solid when cooled. It has low in calories and can easily melt in the mouth. Gelatine can be classified into two types which are Type A (produce from acid-treated collagen) and Type B (produce from alkaline treated collagen) (Ahmad and Benjakul, 2011). There are three major steps in extraction, which are pre-treatment (alkaline or acid), followed by extraction with warm water at certain temperatures. By undergoes this process, it will be converted collagen into gelatine. The last and most crucial step is a clarification that involves filtration, concentration, drying, and milling (Schrieber and Gareis, 2007). Different raw materials used in producing gelatine required a specific extraction process as it will determine the quality of gelatine produced (Khiari et al., 2013). The extraction process designed will influence the functional properties of gelatine. A few processing parameters which are temperature, time, and $\mathrm{pH}$ was designed accordingly to every sample to produce high-quality gelatine. $\mathrm{pH}$ is one of the parameters that majorly contribute to the successfulness of gelatine extraction.

Normally, gelatine is extracted from the fishbone produced from acid-treated collagen (Type A). Usually, hydrochloric acid $(\mathrm{HCl})$ which is inorganic acid was used to break down the bond during the extraction process. As health and green environment issues arise nowadays, organic acid may be one of the alternatives that can be used to replaced inorganic acid during the extraction process for gelatine production. Besides, gelatine production industries especially in small industries face some problems to get inorganic acid chemicals such as acid and base for producing the gelatine. Organic acids are derived from organic compounds such as animal, plant, and microbial sources as they retain acidic properties (Papagianni, 2019). Nypa fruticans, commonly known as the nipa palm (nipa or mangrove palm) is a plant used in producing fruit vinegar of organic acids in Terengganu. It is locally known as nipa palm vinegar and is traditionally produced by fermentation of a nipa palm (Yusuf et al., 2015). The chemical properties of nipa palm were stated as nipa palm lignin mainly consists of guaiacyl and syringyl propane units with a small amount of p-hyroxyphenyl propane, phenolic and many others (Tamunaidu and Saka, 2011; Chatatikun and Kwanhian, 2020). Fermented nipa palm vinegar is one of the organic acids produced by organic sources. Therefore, this study was focused on extracting gelatine from fishbone by replacing inorganic acid with an organic acid, which is the fruit vinegar (nipa palm vinegar) purchased from local industry and also to determine the effects of acid used during extraction on the physicochemical properties of $S$. fimbriata gelatine.

\section{Materials and methods}

\subsection{Preparation of raw materials}

Sardinella fimbriata bones were collected from the local fish processing industry and were cleaned from impurities. The bones were undergone series of boiling and washing processes to remove excessive flesh and unwanted materials. The cleaned and dried bones were then stored at $-20^{\circ} \mathrm{C}$ until further used.

\subsection{Extraction of gelatine from Sardinella fimbriata bones}

Treatment 1 was carried out according to the method of Sanaei et al. (2013) in which the bones were treated in $1 \mathrm{M}$ of inorganic acid $(\mathrm{HCl})$ at $4^{\circ} \mathrm{C}$ for $14 \mathrm{hrs}$. The bones were then neutralized by washing four times under tap water until their $\mathrm{pH}$ was 7 . The bones were washed again with distilled water to remove any residuals and were mixed with distilled water at a ratio of 1:8 $(\mathrm{g}: \mathrm{mL})$. They were extracted at $67^{\circ} \mathrm{C}$ for $5 \mathrm{hrs}$ in a water bath. Gelatine solutions were filtered and centrifuged at $7800 \times g$ at $4^{\circ} \mathrm{C}$ for 20 mins. The solutions were dried in an oven at $60^{\circ} \mathrm{C}$ for $72 \mathrm{hrs}$. Dried gelatines were then packed in ziplocked bags and stored in a desiccator.

Treatment 2 was carried out according to the method of Sanaei et al. (2013). The bones were treated in organic acid (fruit vinegar) at $4{ }^{\circ} \mathrm{C}$ for $14 \mathrm{hrs}$. The bones were then neutralized by washing four times under tap water until their $\mathrm{pH}$ was 7 . The bones were washed again with distilled water to remove any residuals and were mixed with distilled water at a ratio of 1:8 $(\mathrm{g}: \mathrm{mL})$. They were then extracted at $67^{\circ} \mathrm{C}$ for $5 \mathrm{hrs}$ in a water bath. Gelatine solutions were filtered and subsequently centrifuged at $7800 \times g$ at $4^{\circ} \mathrm{C}$ for 20 mins. The solutions were dried in an oven at $60^{\circ} \mathrm{C}$ for $72 \mathrm{hrs}$. Dried gelatines were then packed in zip-locked bags and stored in a desiccator.

\subsection{Yield of gelatine}

The percentage of yield was calculated according to Sanaei et al. (2013). Gelatine obtained was calculated based on the following formula:

Percentage yield of gelatine $=\frac{\text { Weight of dried gelatine }(\mathrm{g}) \times 100}{\text { Weight of dried fishbone }(\mathrm{g})}$

\subsection{Proximate composition}

Protein, ash, moisture and lipid content were analysed according to AOAC (2000) method. The results of the samples were measured and recorded in triplicates. 


\subsection{Physical measurement of gelatine}

\subsubsection{Gel strength}

The gel strength of gelatine was determined according to Gómez-Guillén et al. (2002) with slight modification. An amount of $6.67 \%(\mathrm{w} / \mathrm{v})$ of the solution was prepared by adding $0.33 \mathrm{~g}$ of gelatine to $5.0 \mathrm{~mL}$ of distilled water and dissolved at $60^{\circ} \mathrm{C}$ for 30 mins. The gelatine solutions were filled in a beaker and allowed to cool for 15 mins at $25^{\circ} \mathrm{C}$. The gelatines were kept in a refrigerator at $4^{\circ} \mathrm{C}$ for $18 \mathrm{hrs}$. The samples were measured by using a texture analyser (TA.XT. PLUS, Stable Micro Systems, United Kingdom) with $5 \mathrm{kN}$ load cell equipped with $1.27 \mathrm{~mm}$ diameter plunger. The maximum forced obtained had penetrated at $4 \mathrm{~mm}$ into the centre of gelatine gel and a penetration speed of 1 $\mathrm{mm} / \mathrm{s}$ was used.

\subsubsection{Melting point}

The melting point of gelatine was determined according to Muyonga et al. (2004b) with slight modification. A $6.67 \%(\mathrm{w} / \mathrm{v})$ of gelatine solutions was prepared by adding $0.33 \mathrm{~g}$ of gelatine to $5.0 \mathrm{~mL}$ of distilled water were prepared and dissolved completely. The gelatine solution was placed in a refrigerator at $4{ }^{\circ} \mathrm{C}$ for $18 \mathrm{hrs}$. The cooled gelatines were immediately transferred into the water at $10^{\circ} \mathrm{C}$. The water was heated by using a hot plate magnetic stirrer. The temperature of the water was increased, and the melting point was defined at which the gel starts to move down. All data were recorded.

\subsection{Chemical measurement of gelatine}

\subsubsection{Molecular weight distribution}

The molecular weight distribution of gelatine was analysed according to Laemmli (1970) with slight modification. An amount of $2 \mathrm{mg} / \mathrm{mL}$ of the gelatine was dissolved in $5 \%$ of SDS solution and the mixture was incubated at $85^{\circ} \mathrm{C}$ in a water bath for $1 \mathrm{hr}$. The mixture was centrifuged at $5000 \times g$ for $5 \mathrm{mins}$ at room temperature to remove undissolved debris. An amount of $200 \mu \mathrm{L}$ of samples was mixed with $200 \mu \mathrm{L}$ of Laemmli sample buffer (4× Laemmli Sample Buffer, Biorad, United States) at a ratio of $1: 1(\mathrm{w} / \mathrm{v})$ and heated for 3 mins in boiling water. Samples were loaded onto the readymade polyacrylamide gel (12\% Mini-Protean TGX Precast Gels, Biorad, United States) and subjected to electrophoresis at a constant voltage of $120 \mathrm{~V}$. The gel then was stained for $4 \mathrm{hrs}$ with commasie blue (Bio-Safe Coomassie Stain, Biorad, United States) and distained with $7.5 \%(\mathrm{v} / \mathrm{v})$ methanol and $5 \%(\mathrm{v} / \mathrm{v})$ acetic acid overnight. Amide range $(10-250 \mathrm{kD})$ molecular weight was used to estimate the molecular weight of gelatine. The gel was photographed using a gel doc.

\subsubsection{Amino acid content}

Amino acid content was determined according to Sanaei et al. (2013) with slight modification. The most important amino acid in gelatine was imino acid which is hydroxyproline and proline. The amount of imino acid represents the quality of the extracted gelatine. An amount of $0.1 \mathrm{~g}$ gelatine sample was dissolved in $5 \mathrm{~mL}$ of $6 \mathrm{M} \mathrm{HCl}$, dried and hydrolyse in the test tube at $110^{\circ} \mathrm{C}$ for $24 \mathrm{hrs}$. The samples were then dissolved in $400 \mu \mathrm{l}$ of $50 \mu \mathrm{mol}$ of Amino Acid Standard. Deionized water was added to make up the solution until $100 \mu \mathrm{L}$. A number of $10 \mu \mathrm{L}$ of the samples were injected. Amino acid content was determined using a High-Performance Liquid Chromatography (HPLC) (1525 Binary HPLC Pump, Waters, United States) equipped with Fluorescence Detector and AccQ Tag Column $(3.9 \times 150 \mathrm{~mm})$. AccQ Eluent A and AccQ Eleunt B or $60 \%$ acetonitrile acid was used as the mobile phase with a flow rate of $1 \mathrm{~mL} /$ min.

\subsubsection{Structural composition}

Fourier - Transform Infrared Spectra (FTIR) analysis was carried out according to Sira (2016). Gelatine samples were subjected to FTIR spectrometer (FTIR-iS10, Thermo Scientific, United States) to identify the functional properties of the gelatine. A number of 2 $\mathrm{mg}$ of gelatine powder were placed on the crystal cell of the FTIR spectrometer and was clamped in close contact with the crystal by a force arm. The FTIR spectra over an absorbance between $500 \mathrm{~cm}^{-1}$ to $4000 \mathrm{~cm}^{-1}$ with a resolution of $4 \mathrm{~cm}^{-1}$ from 32 scans were recorded. The spectra were analysed using the Omnic 5.0 spectroscopic software.

\subsection{Statistical analysis}

The average means value was calculated from three replicate of each experiment and expressed with standard deviations. All data were subjected to Analysis of Variance (ANOVA) and the differences between means were evaluated by post hoc test. The SPSS statistic program (IBM SPSS Statistics version 22.0) was used for data analysis. The level of significant difference was considered at $(\mathrm{P}<0.05)$.

\section{Results and discussion}

\subsection{Gelatine yield and proximate composition}

Treatment 1 represented gelatine extracted using inorganic acid $(\mathrm{HCl})$ while Treatment 2 represented the gelatine extracted using organic acid (fruit vinegar). The yield and the proximate content of the Treatment 1 and Treatment 2 were recorded and compared to each other. All data were shown in Table 1. 
Table 1. Yield and proximate composition of gelatine from Treatment 1, Treatment 2 and Control

\begin{tabular}{lccc}
\hline Analysis (\%) & Treatment 1 & Treatment 2 & Control \\
\hline Yield & $6.0 \pm 0.03^{\mathrm{a}}$ & $2.9 \pm 0.01^{\mathrm{b}}$ & - \\
Protein & $59.1 \pm 0.29^{\mathrm{b}}$ & $43.9 \pm 0.38^{\mathrm{c}}$ & $82.2 \pm 4.88^{\mathrm{a}}$ \\
Moisture & $14.3 \pm 0.21^{\mathrm{b}}$ & $16.1 \pm 0.68^{\mathrm{c}}$ & $13.1 \pm 0.55^{\mathrm{a}}$ \\
Lipid & $0.76 \pm 0.44^{\mathrm{a}}$ & $0.89 \pm 0.31^{\mathrm{a}}$ & $0.41 \pm 0.21^{\mathrm{a}}$ \\
Ash & $4.7 \pm 0.21^{\mathrm{b}}$ & $5.5 \pm 0.13^{\mathrm{c}}$ & $2.3 \pm 0.11^{\mathrm{a}}$ \\
\hline
\end{tabular}

Values are presented as mean \pm standard deviation of triplicate. Values with different superscript in the same row are significantly different $(\mathrm{P}<0.05)$.

The results show Treatment 2 has a lower yield percentage $(2.9 \pm 0.01)$ compared to Treatment 1 (6.0 \pm 0.03$)$. The different amounts of yield may be due to the different types of acid used in the extraction process (Niu et al., 2013). Inorganic acid ( $\mathrm{HCl})$ used in Treatment 1 was a strong acid while organic acid (fruit vinegar) used in Treatment 2 was a weak acid. A strong acid has a greater number of reactive hydrogen ions and resulted in a higher yield during the extraction process (Niu et al., 2013). Moreover, strong acid produces more hydrogen ions than weak acid and is easier to facilitate the dissolution of the intra- and intermolecular crosslinked collagen. When these cross-linking are cleaved, the triple helix structure of collagen was changed to random coils and gelatine were produced (Sri et al., 2017).

Treatment 1 indicated higher protein content $(59.1 \pm 0.29 \%)$ compared to Treatment $2(43.9 \pm 0.38 \%)$ but lower than control $(82.2 \pm 4.88 \%)$. As stated by Muyonga et al. (2004a), the amount of protein content was related to the amount of yield produced. Higher of protein content resulted in higher of production of yield. This is in good alignment with the previous findings on the yield percentage of gelatine that shows Treatment 1 has higher yield production than Treatment 2 . This may be due to the different acid used during extraction process (Kusumaningrum et al., 2018).

The highest moisture content was obtained from Treatment $1(14.3 \pm 0.21 \%)$. Followed by Treatment 2 $(16.1 \pm 0.68 \%)$ and control $(13.1 \pm 0.55 \%)$, respectively. This result shows that control has lower moisture content compare to Treatment 1 and Treatment 2. A previous study carried out by Kusumaningrum et al. (2018) stated that the maximum amount of moisture content for gelatine ranging from $14 \%$ to $16 \%$. This means the result of moisture content for both treatments are within the range and can be accepted.

Treatment 2 shows higher lipid content compared to Treatment 1 and control samples with the amount of $0.89 \pm 0.31 \%, 0.76 \pm 0.44 \%$ and $0.41 \pm 0.21 \%$, respectively. The lipid content of Treatment 1, Treatment 2 and
Control were still in an accepted range which is less than $1 \%$ (Cho et al., 2004).

The results obtained for ash content for all samples were $4.7 \pm 0.21 \%$ for Treatment $1,5.5 \pm 0.13 \%$ for Treatment 2 and $2.3 \pm 0.11 \%$ for control. It shows that Control has a much lower ash content compared to Treatment 1 and Treatment 2. Usually, the amount of ash content up to $2.0 \%$ can be accepted in food applications (Cho et al., 2004). This means these results can be accepted. Besides, the different amounts of ash found in this study may probably be due to the different amounts of minerals from the fish bones (Khiari et al., 2011).

\subsection{Physical measurement of gelatine: gel strength, and melting point}

Gel strength and melting point are some of the most important physical properties of gelatine (Sanaei et al., 2013). These properties were specifying the most suitable industry gelatine that can be applied. Table 2 shows the gel strength and melting point of gelatine extracted from Treatment 1, Treatment 2, and Control.

Table 2. Gel strength and melting point of gelatine from Treatment 1, Treatment 2 and Control.

\begin{tabular}{lccc}
\hline Analysis & Treatment 1 & Treatment 2 & Control \\
\hline Gel strength $(\mathrm{g})$ & $132.4 \pm 2.64^{\mathrm{a}}$ & $75.9 \pm 1.06^{\mathrm{b}}$ & $350.5 \pm 8.48^{\mathrm{c}}$ \\
Melting point $\left({ }^{\circ} \mathrm{C}\right)$ & $25 \pm 1.52^{\mathrm{a}}$ & $22.0 \pm 1.00^{\mathrm{b}}$ & $38 \pm 1.53^{\mathrm{c}}$ \\
\hline
\end{tabular}

Values are presented as mean \pm standard deviation of triplicate. Values with different superscript in the same row are significantly different $(\mathrm{P}<0.05)$.

The gel strength of gelatine for all samples was $132.4 \pm 2.64 \mathrm{~g}, \quad 75.9 \pm 1.06 \mathrm{~g}$ and $350.5 \pm 8.48 \mathrm{~g}$ respectively. According to a previous study, the gel strength of fish gelatine ranging from 124 to $426 \mathrm{~g}$ compared to 200 to $350 \mathrm{~g}$ for commercial gelatine such as bovine and porcine (Khiari et al., 2011). It means that gelatine from this study was still in the range and can be accepted. Results show Treatment 1 has better gel strength compare to Treatment 2 but is poor than the Control. Treatment 1 used inorganic acid $(\mathrm{HCl})$ which is strong acid while Treatment 2 used organic acid (fruit vinegar) which is a weak acid. The different values of gel strength may be affected by the extraction process (Tinrat and Sila-Asna, 2017). Herpandi et al. (2011) revealed that Salmon and Bigeye snapper had the gel strength of $108.0 \mathrm{~g}$ and $105.7 \mathrm{~g}$, respectively is lower than that of gelatine from Treatment 1 in this study. Unfortunately, the gel strength of Nile tilapia which is $252.0 \mathrm{~g}$ was higher than Treatment 1 and Treatment 2. The variation value of gel strength among these species may be due to imino acid content which is proline and hydroxyproline. According to a previous study, the difference in gel strength correlated to amino acid 
composition and size of the protein chain (Muyonga et al., 2004b). Low gel strength value may result from low concentration and molecular weight distribution (Ockerman and Hansen, 1988).

Gelatine gel will start to melt at a certain temperature called the gel melting point. The melting point for fish gelatine and bovine range from 11 to $28^{\circ} \mathrm{C}$ and 28 to $38^{\circ}$ $\mathrm{C}$ respectively. In this study, Table 2 shows the result of the melting point of gelatine from Treatment 1, Treatment 2 and Control. The results were $25 \pm 1.52^{\circ} \mathrm{C}$, $22.0 \pm 1.00$ and $38 \pm 1.53^{\circ} \mathrm{C}$ respectively. Treatment 1 has a higher melting point compared to Treatment 2 but is lower than Control. Fish gelatine usually has a much lower melting point compared to mammalian gelatine such as bovine and porcine (Cho et al., 2005). This is further supported by the previous study conducted at other species such as Sin croaker, Cod, Yellow tuna and Tilapia that have $18.5^{\circ} \mathrm{C}, 13.5^{\circ} \mathrm{C}, 24.5^{\circ} \mathrm{C}$ and $25.4^{\circ} \mathrm{C}$, respectively. Different melting point values may be due to different amino acid content. It is interesting to find out from the previous study that the lower amino acid contents and less proline and hydroxyproline were affected the characteristics of melting point (GómezGuillén et al., 2002). Besides, the origin of the raw material used in the process gives greatly influenced the melting point values (Gilsenan and Ross-Murphy, 2000).

\subsection{Chemical measurement of gelatine: molecular weight distribution, amino acid, and structure composition}

The protein pattern of gelatine was determined by using SDS-PAGE as shown in Figure 1. Gelatine commonly consists of a mixture of a fragment with molecular weights in the range from 80 to $250 \mathrm{kDa}$ (Karim and Bhat, 2009). Treatment 1 and Treatment 2 were characterized as type 1 collagens due to the presence of $\alpha_{1}, \alpha_{2}$ and $\beta$ chains (Benjakul et al., 2009). Each treatment shows that the molecular weight for $\alpha_{1}$ and $\alpha_{2}$ chains was around $100 \mathrm{kDa}$, while $\beta$ chains were around $200 \mathrm{kDa}$. The vary of molecular weight distribution may be related to the extraction process (Jongjareonrak et al., 2010) Gelatine with the higher content of $\alpha$ chain has better gel strength (Nagarajan et al., 2012). This is in good alignment with previous findings in gel strength that shows Treatment 1 has a good gelling ability. In addition, the distribution of molecular weight also affected the amount of amino acid composition (Jongjareonrak et al., 2010). The presence of $\beta$ chains was related to the intermolecular cross-linked (Kim, 2013). A large amount of $\beta$ chains reported showing a negative effect on the functional properties of gelatine such as lower viscosity and melting point (Muyonga et al., 2014b). It shows that this result can be accepted because each treatment has a lower melting point as shows in the melting point part.

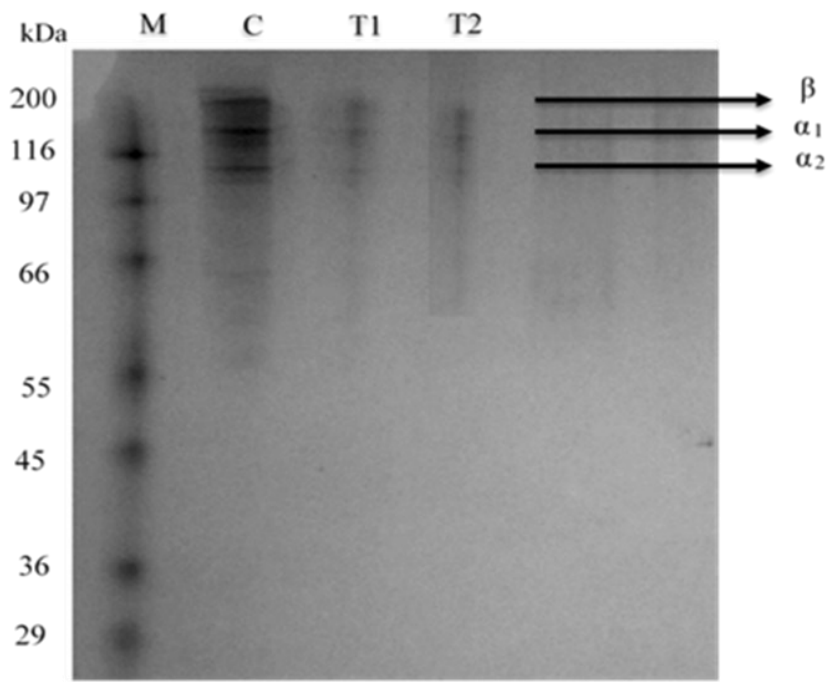

Figure 1. SDS-PAGE pattern of gelatine extracted from Treatment 1 (T1), Treatment 2 (T2) and Control (C) while M as a marker.

Table 3. Amino acid compositions $(\mathrm{mg} / \mathrm{g})$ of gelatine from Treatment 1, Treatment 2 and Control.

\begin{tabular}{lccc}
\hline \multicolumn{3}{c}{ Amino acids $\quad \mathrm{g} / \mathrm{mg})$} & \multicolumn{3}{c}{ Samples } \\
\cline { 2 - 4 } & Treatment 1 & Treatment 2 & Control \\
\hline Glutamic acid & $88.77 \pm 4.6^{\mathrm{a}}$ & $46.03 \pm 7.20^{\mathrm{b}}$ & $156.19 \pm 15.75^{\mathrm{c}}$ \\
Phenylalanine & $20.82 \pm 0.34^{\mathrm{a}}$ & $8.93 \pm 1.53^{\mathrm{b}}$ & $45.51 \pm 7.09^{\mathrm{c}}$ \\
Tyrosine & $6.87 \pm 0.11^{\mathrm{a}}$ & $3.97 \pm 0.49^{\mathrm{b}}$ & $17.47 \pm 2.98^{\mathrm{c}}$ \\
Glycine & $209.50 \pm 6.32^{\mathrm{a}}$ & $88.33 \pm 16.34^{\mathrm{b}}$ & $373.91 \pm 6.21^{\mathrm{c}}$ \\
Proline & $107.65 \pm 3.25^{\mathrm{a}}$ & $43.77 \pm 8.21^{\mathrm{b}}$ & $225.84 \pm 3.93^{\mathrm{c}}$ \\
Alanine & $96.64 \pm 3.68^{\mathrm{a}}$ & $40.07 \pm 8.20^{\mathrm{b}}$ & $147.20 \pm 6.34^{\mathrm{c}}$ \\
Methionine & $26.55 \pm 0.20^{\mathrm{a}}$ & $10.53 \pm 2.12^{\mathrm{b}}$ & $28.13 \pm 3.87^{\mathrm{a}}$ \\
Hydroxyproline & $89.05 \pm 0.49^{\mathrm{a}}$ & $34.99 \pm 6.5^{\mathrm{b}}$ & $230.66 \pm 26.6^{\mathrm{c}}$ \\
Aspartic acid & $51.27 \pm 3.53^{\mathrm{a}}$ & $24.62 \pm 4.32^{\mathrm{b}}$ & $86.55 \pm 11.82^{\mathrm{c}}$ \\
Valine & $21.81 \pm 0.32^{\mathrm{a}}$ & $9.82 \pm 1.58^{\mathrm{b}}$ & $49.43 \pm 2.32^{\mathrm{c}}$ \\
Isoleucine & $10.24 \pm 0.03^{\mathrm{a}}$ & $5.07 \pm 0.63^{\mathrm{b}}$ & $23.46 \pm 1.33^{\mathrm{c}}$ \\
Leucine & $23.53 \pm 0.22^{\mathrm{a}}$ & $10.00 \pm 1.69^{\mathrm{b}}$ & $54.75 \pm 2.52^{\mathrm{c}}$ \\
Lysine & $32.76 \pm 1.81^{\mathrm{a}}$ & $15.99 \pm 2.69^{\mathrm{b}}$ & $61.92 \pm 4.63^{\mathrm{c}}$ \\
Serine & $33.70 \pm 0.14^{\mathrm{a}}$ & $15.13 \pm 2.60^{\mathrm{b}}$ & $70.68 \pm 8.09^{\mathrm{c}}$ \\
Histidine & $9.83 \pm 0.22^{\mathrm{a}}$ & $3.83 \pm 0.69^{\mathrm{b}}$ & $20.43 \pm 3.95^{\mathrm{c}}$ \\
Arginine & $80.61 \pm 0.87^{\mathrm{a}}$ & $32.25 \pm 5.64^{\mathrm{b}}$ & $169.51 \pm 25.53^{\mathrm{c}}$ \\
Threonine & $23.95 \pm 0.14^{\mathrm{a}}$ & $10.14 \pm 1.74^{\mathrm{b}}$ & $40.39 \pm 6.57^{\mathrm{c}}$ \\
\hline
\end{tabular}

Values are presented as mean \pm standard deviation of triplicate. Values with different superscript in the same row are significantly different $(\mathrm{P}<0.05)$.

The amino acid composition is one of the important elements to characterize the quality of the gelatin. Table 3 shows the amino acid composition of gelatin from Treatment 1, Treatment 2 and Control. There was 17 amino acid that found in these gelatines. The most dominant amino acid in Treatment 1, Treatment 2 and Control was glycine that resulted in $209.50 \pm 6.32$, $88.33 \pm 16.34$ and $373.91 \pm 6.21$ respectively. These results were further supported by a previous study that state glycine was the dominant amino acid found in Carp 
gelatine (Duan et al., 2009). Treatment 1 and treatment 2 have lower glycine compare to Control. The result obtained was consistent with the finding by Zhang et al. (2011) and Liu et al. (2008) stated that fish gelatine had lower quantities of glycine compared to the commercial gelatine.

The most important amino acid in gelatine was proline and hydroxyproline, called imino acid. The stability of the triple helix structure in denatured gelatine is generally affected by the content of the amino acid (Nikoo et al., 2011). Hydroxyproline plays a major role in the stabilization of the triple helix structure. This means gelatine has high imino acid content tend to have a better characteristic such as melting point, gel strength and viscosity. This is further supported by a previous study by Shyni et al. (2014) reported that the variation amount of imino acid especially hydroxyproline were affected by the viscosity and gel formation of the gelatine.

Treatment 1 shows higher imino acid content which has $107.65 \pm 3.25 \mathrm{~g} / \mathrm{mg}$ of proline and $89.05 \pm 0.49 \mathrm{~g} / \mathrm{mg}$ of hydroxyproline compare to Treatment 2 . Treatment 2 only has $43.77 \pm 8.21 \mathrm{~g} / \mathrm{mg}$ of proline and $34.99 \pm 6.50 \mathrm{~g} /$ $\mathrm{mg}$ of hydroxyproline. The difference in such results may be due to the difference in acid used during the extraction process. It was being proven by the previous study that shows the different amounts of hydroxyproline content was affected by the extraction process (Nikoo et al., 2011). However, imino acid content in Treatment 1 and Treatment 2 was lower compared to the Control. Control gelatine has $225.84 \pm 3.93 \mathrm{~g} / \mathrm{mg}$ of proline and $230.66 \pm 26.6 \mathrm{~g} / \mathrm{mg}$ of hydroxyproline. Generally, mammalian gelatine contains higher imino acids compare to fish gelatine (Shyni et al., 2014). Gelatine with low imino acid content tends to have a low melting point and gel strength (Muyonga et al., 2004b). This is in good alignment with the previous findings which shows Treatment 1 and Treatment 2 have a lower gel strength and melting point than a Control.

Fourier transform infrared spectroscopy (FTIR) analysis was conducted to observe and compare the main structural characteristics of the gelatine from Treatment 1, Treatment 2 and Control. Comparison between this gelatine was based on the comparison absolute peak intensity. The region was divided into several regions which are amide A, amide B, amide I, amide II and amide III (Kong and $\mathrm{Yu}, 2007$ ). Similar results were shown in this study which has amide A, amide B, amide I, amide II and amide III for all gelatine.

There were five basic regions involved known as amide A, amide B, amide I, amide II and lastly amide III. The characteristic of the amide group was an exhibit by protein due to the absorption bands in the infrared spectra. This absorption is due to $\mathrm{C}=\mathrm{O}$ stretching, $\mathrm{N}-\mathrm{H}$ stretching, C-N stretching and O-C-N bending. All the gelatine shows similar spectra, in which the absorption bands are situated in the amide region. Besides, these gelatine samples had major peaks in the amide region. However, it also shows there were slight differences in spectra.

There were three major peaks regions know as regions 1,2 and 3. Figure 2 shows three major peak regions for Treatment 1, Treatment 2 and Control. Treatment 1 resulted three major peak regions as $1(3400$ to $1800 \mathrm{~cm}^{-1}$ ), 2 (1750 to $1300 \mathrm{~cm}^{-1}$ ) and 3 (1200 to 700 $\mathrm{cm}^{-1}$ ). Amide A was $3232.25 \mathrm{~cm}^{-1}$, amide B was 2968.04 $\mathrm{cm}^{-1}$, amide I was $1633.00 \mathrm{~cm}^{-1}$, amide II was 1538.50 $\mathrm{cm}^{-1}$, and lastly, amide III was $1057.33 \mathrm{~cm}^{-1}$. While Treatment 2 show region 1 (3650 to $\left.1800 \mathrm{~cm}^{-1}\right), 2(1750$ to $\left.1300 \mathrm{~cm}^{-1}\right)$, and $3\left(1250\right.$ to $\left.550 \mathrm{~cm}^{-1}\right)$. The wavenumber of amide $\mathrm{A}$, amide $\mathrm{B}$, amide $\mathrm{I}$, amide II, and amide III were $3232.25 \mathrm{~cm}^{-1}, 2968.04 \mathrm{~cm}^{-1}, 1621.90$ $\mathrm{cm}^{-1}, 1538.50 \mathrm{~cm}^{-1}$, and $1053.95 \mathrm{~cm}^{-1}$ respectively. Control shows the wavenumber of regions 1,2 and 3 where 3600 to $1800 \mathrm{~cm}^{-1}, 1750$ to $1350 \mathrm{~cm}^{-1}$, and 1200 to $500 \mathrm{~cm}^{-1}$ respectively. The regions were divided into amide A (3280.62 $\left.\mathrm{cm}^{-1}\right)$, amide B $\left(2969.00 \mathrm{~cm}^{-1}\right)$, amide I $\left(1634.44 \mathrm{~cm}^{-1}\right)$, amide II $\left(1538.98 \mathrm{~cm}^{-1}\right)$, and amide III

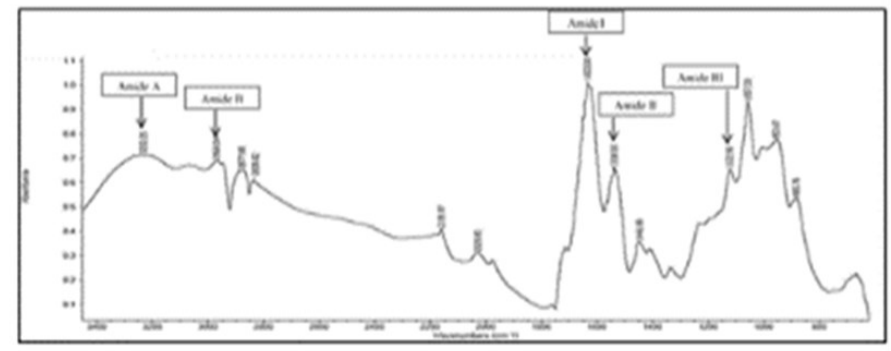

Treatment 1

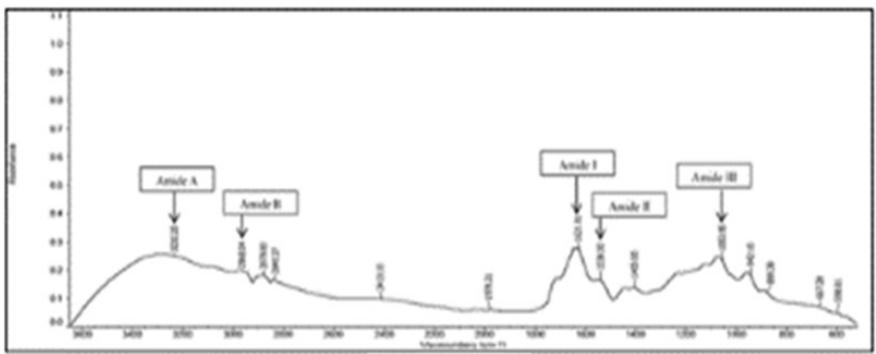

Treatment 2

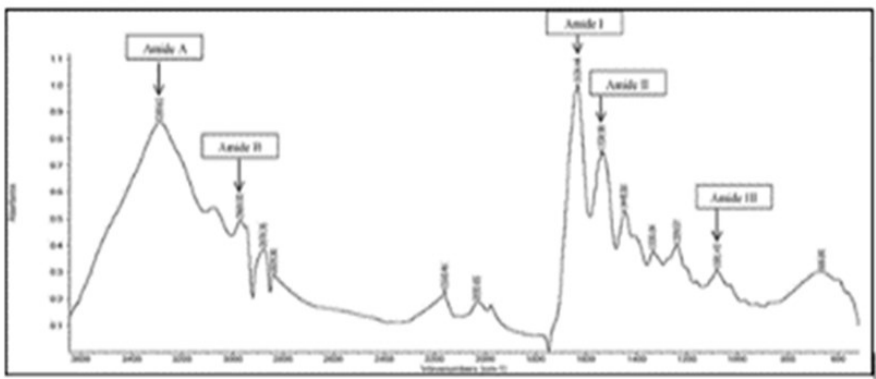

Control

Figure 2. FTIR spectrum of Treatment 1, Treatment 2 and control gelatine demonstrated three major peaks. 
$\left(1081.43 \mathrm{~cm}^{-1}\right)$.

The intensity of amide I was the result of $\mathrm{C}=\mathrm{O}$ stretching vibration coupled with $\mathrm{C}-\mathrm{N}$ stretch and $\mathrm{CNN}$ deformation (Liu et al., 2012). While amide II peak was a result of $\mathrm{N}-\mathrm{H}$ bending and $\mathrm{C}-\mathrm{N}$ stretching vibration (Cebi et al., 2016). Amide III is generally related to C-N stretching and N-H bending, it also includes vibration of the triple helix structure (Muyonga et al., 2004a). Amide I and amide II for all gelatine in this study were observed was slightly different which ranging from 1700 to 1600 $\mathrm{cm}^{-1}$ and 1560 to $1500 \mathrm{~cm}^{-1}$ respectively. It is in good alignment with the previous study by Muyonga et al. (2004a) and Yakimets et al. (2005) which have similar results. However, the different spectral values among this gelatine may be due to the different conformation and orientation of polypeptide chains. A previous study also shows that a lower wavenumber was resulted in a decrease in molecular order due to conformational change (Ahmad et al., 2011). Amide I is the most important for the determination of the secondary structure of protein due to the $\mathrm{C}=\mathrm{O}$ stretch vibration of peptide linkages (Jackson and Mantsch, 1995).

The wavenumber of amide III was $1057.33 \mathrm{~cm}^{-1}$ for Treatment 1, $1053.95 \mathrm{~cm}^{-1}$ for Treatment 2 and 1081.43 $\mathrm{cm}^{-1}$ Control. These results show that both treatments have a much lower wavenumber compare to the Control gelatine. This is maybe due to a greater disorder from the $\alpha$-helical to a random coil structure (Friess and Lee, 1996). A previous study also reported that a lower wavenumber may be due to loss of triple helix states and denaturation of collagen to protein (Muyonga et al., 2004a). The wavenumber of amide A for Treatment 1 was $3232.25 \mathrm{~cm}^{-1}$ and Treatment 2 was $3289.62 \mathrm{~cm}^{-1}$. Generally, amide A mainly associated with the N-H stretching due to the existence of a hydrogen bond. According to a previous study, the position N-H group of peptides was shifted to lower frequencies when the hydrogen bond involved (Jridi et al., 2013).

\section{Conclusion}

Overall findings have suggested that different types of acid used in the extraction process resulted in different physico-chemical properties of the gelatine. Findings from this study have suggested that $S$. fimbriata bone hold the potential to be an alternative source for vast applications in industries. $S$. fimbriata bone gelatine may demonstrate low properties, however, it is comparable to other species carried out in previous studies. It can be used in the food and beverages industry that require low gel strength value in the formulation ingredients. Further research on the potential properties of S. fimbriata bone gelatine should be carried out to better understand its potential for Halal and Kosher markets.

\section{Conflict of interest}

The authors declare no conflict of interest.

\section{Acknowledgements}

This research was supported by Research Acculturation Grant Scheme (RAGS), Ministry of Higher Education, Malaysia [Vot. No 57119].

\section{References}

Ahmad, M. and Benjakul, S. (2011). Characteristics of gelatine from the skin of unicorn leatherjacket (Aluterus monoceros) as influenced by acid pretreatment and extraction time. Food Hydrocolloids, 25(3), 381-388. https://doi.org/10.1016/ j.foodhyd.2010.07.004

Ahmad, M., Benjakul, S., Ovissipour, M. and Prodpran, T. (2011). Indigenous proteases in the skin of unicorn leatherjacket (Alutherus monoceros) and their influence on characteristic and functional properties of gelatin. Food Chemistry, 127(2), 508515. https://doi.org/10.1016/j.foodchem.2011.01.032

Ambak, M.A., Isa, M.M., Zakaria, M.Z. and Ghaffar, M.A. (2010). Fishes of Malaysia. Kuala Terengganu, Malaysia: Universiti Malaysia Terengganu.

AOAC. (2000). Official methods of analysis. 15th ed. Virginia: Association of Official Analytical Chemists, Inc.

Benjakul, S., Oungbho, K., Visessanguan, W., Thiansilakul, Y. and Roytrakul, S. (2009). Characteristics of gelatin from the skins of bigeye snapper, Priacanthus tayenus and Priacanthus macracanthus. Food Chemistry, 116(2), 445-451. https://doi.org/10.1016/j.foodchem.2009.02.063

Cebi, N., Durak, M.Z., Toker, O.S., Sedgic, O. and Arici, M. (2016). An evaluation of Fourier transforms infrared spectroscopy method for the classification and discrimination of bovine, porcine and fish gelatines. Food Chemistry, 190, 1109-1115. https:// doi.org/10.1016/j.foodchem.2015.06.065

Chatatikun, M. and Kwanhian, W. (2020). Phenolic profile of nipa palm vinegar and evaluation of its antilipidemic activities. Evidence-Based Complementary and Alternative Medicine, 2020, 6769726. https://doi.org/10.1155/2020/6769726

Cho, S.M., Gu, Y.S. and Kim, S.B. (2005). Extraction optimization and physical properties of Yellow-fin Tuna (Thunnus albacares) skin gelatine compared to mammalian gelatine. Food Hydrocolloids, 19(2), 221-229. 
j.foodhyd.2004.05.005

Cho, S.M., Kwak, K.S., Park, D.C., Gu, Y.S., Ji, C.I., Jang, D.H., Lee, Y.B. and Kim, S.B. (2004). Processing optimization and functional properties of gelatine from Shark (Isurus oxyrinchus) cartilage. Food Hydrocolloids, 18(4), 573-579. https:// doi.org/10.1016/j.foodhyd.2003.10.001

Duan, R., Zhang, J., Du, X., Yao, X. and Konno, K. (2009). Properties of collagen from skin, scale and bone of carp (Cyprinus carpio). Food Chemistry, 112(3), 702-706. https://doi.org/10.1016/ j.foodchem.2008.06.020

Friess, W. and Lee, G. (1996). Basic thermoanalytical studies of insoluble collagen matrices. Biomaterials, 17(23), 2289-2294. https://doi.org/10.1016/01429612(96)00047-6

Gilsenan, P.M. and Ross-Murphy, S.B. (2000). Rheological characterisation of gelatines from mammalian and marine sources. Food Hydrocolloids, 14(3), 191-195. https:// doi.org/10.1016/S0268-005X(99)00050-8

Gómez-Guillén, M.C., Turnay, J., Fernández-Diaz, M.D., Ulmo, N., Lizarbe, M.A. and Montero, P. (2002). Structural and physical properties of gelatine extracted from different marine species: A comparative study. Food Hydrocolloids, 16(1), 2534. https://doi.org/10.1016/S0268-005X(01)00035-2

Herpandi., Huda, N. and Adzitey, F. (2011). Fish bone and scale as a potential source of halal gelatine. Journal of Fisheries and Aquatic Science, 6(4), 379389. https://doi.org/10.3923/jfas.2011.379.389

Jackson, M. and Mantsch, H.H. (1995). The use and misuse of FTIR spectroscopy in the determination of protein structure. Critical Reviews in Biochemistry and Molecular Biology, 30(2), 95-120. https:// doi.org/10.3109/10409239509085140

Jespersen, C., Christiansen, K. and Hummelmose, B. (2000). Cleaner production assessment in fish processing. Prepared by COWI consulting engineers and planners AS, Denmark: United Nations Environment Programme, Division of Technology, Industry and Economics.

Jongjareonrak, A., Rawdkuen, S., Chaijan, M., Benjakul, S., Osako, K. and Tanaka, M. (2010). Chemical compositions and characterisation of skin gelatine from farmed giant catfish (Pangasianodon gigas). LWT-Food Science and Technology, 43 (1), 161-165. https://doi.org/10.1016/ j.lwt.2009.06.012

Jridi, M., Nasri, R., Lassoued, I., Souissi, N., Mbarek, A., Barkia, A. and Nasri, M. (2013). Chemical and biophysical properties of gelatins extracted from alkali-pretreated skin of cuttlefish (Sepia officinalis) using pepsin. Food Research International, 54(2), 1680-1687.

j.foodres.2013.09.026

Karim, A.A. and Bhat, R. (2009). Fish gelatine: properties, challenges and prospects as an alternative to mammalian gelatine. Food Hydrocolloids, 23(3), 563-576.

j.foodhyd.2008.07.002

https://doi.org/10.1016/

Khiari, Z., Rico, D., Martin-Diana, A.B. and BarryRyan, C. (2013). Comparison between gelatines extracted from Mackerel and Blue Whiting bones after different pre-treatments. Food Chemistry, 139(1 -4), 347-354. https://doi.org/10.1016/ j.foodchem.2013.01.017

Khiari, Z., Rico, D., Martin-Diana, A.B. and BarryRyan, C. (2011). The extraction of gelatine from mackerel (Scomber scombrus) heads with the use of different organic acids. Journal of FisheriesSciences.com, 5(1), 52-63. https:// doi.org/10.3153/jfscom.2011007

Kim, S.K. (2013). Marine Proteins and Peptides: Biological Activities and Applications. 1st ed. West Sussex, United Kingdom: John Wiley and Sons, Ltd.

Kong, J. and Yu, S. (2007). Fourier transform infrared spectroscopic analysis of protein secondary structures. Acta Biochimica et Biophysica Sinica, 39 (8), 549-559. https://doi.org/10.1111/j.17457270.2007.00320.x

Kusumaningrum, I., Pranoto, Y. and Hadiwiyoto, S. (2018). Extraction optimization and characterization of gelatine from fish dry skin of Spanish mackerel (Scomberromorus commersoni). IOP Conference Series: Earth and Environmental Science, 144, 012036. https://doi.org/10.1088/1755$1315 / 144 / 1 / 012036$

Laemmli, U.K. (1970). Cleavage of structural proteins during the assembly of the head of bacteriophage T4. Nature, 227(5259), 680-685. https:// doi.org/10.1038/227680A0

Liu, D., Liang, L., Regenstein, J.M. and Zhou, P. (2012). Extraction and characterisation of pepsin-solubilised collagen from fins, scales, skins, bones, and swim bladders of bighead carp (Hypopthalmichtys nobilis). Food Chemistry, 133(4), 1441-1448. https:// doi.org/10.1016/j.foodchem.2012.02.032

Liu, H.Y., Li, D. and Guo, S.D. (2008). Extraction and properties of gelatine from channel catfish (Ietalurus punetaus) skin. LWT-Food Science and Technology, 41(3), 414-419. https://doi.org/10.1016/ j.lwt.2007.03.027

Mohtar, N.F. Conrad, P. and Siew, Y.Q. (2010). 
Optimisation of gelatine extraction from hoki (Macruronus novaezelandiae) skins and measurement of gel strength and SDS-PAGE. Food Chemistry, 122(1), 307-313. https://doi.org/10.1016/ j.foodchem.2010.02.027

Muyonga, J.H., Cole, C.G.B. and Duodu, K.G. (2004a). Fourier transform infrared (FTIR) spectroscopic study of acid soluble collagen and gelatine from skins and bones of young and adult Nile perch (Lates niloticus). Food Chemistry, 86(3), 325-332. https:// doi.org/10.1016/j.foodchem.2003.09.038

Muyonga, J.H., Cole, C.G.B. and Duodu, K. G. (2004b). Extraction and physico-chemical characterisation of Nile perch (Lates niloticus) skin and bone gelatine. Food Hydrocolloids, 18(4), 581-592. https:// doi.org/10.1016/j.foodhyd.2003.08.009

Nagarajan, M., Benjakul, S., Prodpran, T., Songtipya, P. and Kishimura, H. (2012). Characteristics and functional properties of gelatine from splendid squid (Loligo formosana) skin as affected by extraction temperature. Food Hydrocolloids, 29(2), 389-397. https://doi.org/10.1016/j.foodhyd.2012.04.001

Nikoo, M., Xu, X., Benjakul, S., Xu, G., RamirezSuarez, J.C., Ehsani, A., Kasankala, L.M., Duan, X. and Abbas, S. (2011). Characterization of gelatine from the skin of farmed Amur sturgeon. Acipenser schrenckii. International Aquatic Research, 3, 135145.

Niu, L., Zhiou, X., Yuan, C., Bai, Y., Lai, K., Yang, F. and Huang, Y. (2013). Characterization of tilapia (Oreochromis niloticus) skin gelatine extracted with alkaline and different acid pretreatments. Food Hydrocolloids, 33(2), 336-341. https:// doi.org/10.1016/j.foodhyd.2013.04.014

Ockerman, H.W. and Hansen, C.L. (1988). Animal by product processing. Chichester, UK: Ellis Horwood Ltd.

Papagianni, M. (2019). 1.07 - Organic acids. Reference Module in Life Sciences. Comprehensive Biotechnology, 3rd ed. Vol. 1, p. 85-97. Elsevier EBook. https://doi.org/10.1016/B978-0-444-640468.00009-4

Sanaei, A.V., Mahmoodani, F., See, S.F., Yusop, S.M and Babji, A.S. (2013). Processing optimization and characterization of gelatine from catfish (Clarias gariepinus) skin. Sains Malaysiana, 42(12), 16971705.

Schrieber, R. and Gareis, H. (2007). Gelatine handbook: Theory and industrial practice. Germany: WileyVCH Verlag GmbH and Co. KGaA,Weinheim.

Shyni, K., Hema, G.S., Ninan, G., Mathew, S., Joshy, C.G. and Lakshmanan, P.T. (2014). Isolation and characterization of gelatine from the skins of skipjack tuna (Katsuwonus pelamis), dog shark (Scoliodon sorrakowah), and rohu (Labeo rohita). Food Hydrocolloids, 39, 68-76. https:// doi.org/10.1016/j.foodhyd.2013.12.008

Sira, C. (2016). Production and characterization of collagen, gelatine and gelatine hydrolysate powder from scales of spotted golden goatfish. Thailand: Prince of Songkla University, Msc. Thesis.

Sri, M., Francis, M.C., Setyabudi, S., Yudi, P. and Umar, S. (2017). Physicochemical properties of gelatin extracted from buffalo hide pretreated with different acids. Korean Journal for Food Science of Animal Resources, 37(5), 708-715. https://doi.org/10.5851/ kosfa.2017.37.5.708

Tamunaidu, P. and Saka, S. (2011). Chemical characterization of various parts of nipa palm (Nypa fruticans). Industrial Crops and Products, 34(3), 1423-1428. https://doi.org/10.1016/ j.indcrop.2011.04.020

Tinrat, S. and Sila-Asna, M. (2017). Optimization of gelatine extraction and physico-chemical properties of fish skin and bone gelatine: Its application to panna cotta formulas. Current Research in Nutrition and Food Science, 5(3), 263-273. http:// dx.doi.org/10.12944/CRNFSJ.5.3.11

Yakimets, I., Wellner, N., Smith, A.C., Wilson, R.H., Farhat, I. and Mitchell, J. (2005). Mechanical properties with respect to water content of gelatine films in glassy state. Polymer, 46(26), 12577-12585. https://doi.org/10.1016/j.polymer.2005.10.090

Yusuf, N.A., Yam, M.F., Beh, H.K., Razak, K.N.A., Widyawati, T., Mahmud, R., Ahmad, M. and Asmawi, M.Z. (2019). Antidiabetic and antioxidant activities of Nypa fruticans Wurmb. vinegar sample from Malaysia. Asian Pacific Journal of Tropical Medicine, 8(8), 595-605. https://doi.org/10.1016/ j.apjtm.2015.07.015

Zhang, F., Xu, S. and Wang, Z. (2011). Pre-treatment optimization and properties of gelatin from freshwater fish scale. Food Bioproduct Processing, 89(3), 185-193. https://doi.org/10.1016/ j.fbp. 2010.05 .003 